\title{
Restorative proctocolectomy with ileal reservoir: a pathophysiological assessment
}

\author{
R J NICHOLLS,* P BELliveAU, M NEILL, M WILKS, AND S TABAQCHALI \\ From the Department of Surgery, St Mark's Hospital, London, and the Department of Microbiology, \\ St Bartholomew's Hospital, London
}

SUMMARY A metabolic and physiological assessment was carried out in 14 patients who had undergone restorative proctocolectomy with ileal reservoir more than six months previously. The haemoglobin was normal in all but one and plasma electrolytes and serum albumin, calcium, phosphorus, and red cell folate estimations were normal in all. Five patients had low serum iron levels of whom one had an iron deficiency anaemia. The 24 hour faecal fat output was normal in all patients and there was no case of vitamin $B_{12}$ malabsorption as judged by the Schilling test, although four patients had marginally low values. These were not associated with increased bacterial counts in the faeces within the reservoir and there was no evidence to support a diagnosis of stagnant loop syndrome. Inflammation of the reservoir mucosa was, however, associated with higher counts of aerobic bacteria than in cases where inflammation was absent. Subtotal villous atrophy or inflammation was seen in biopsies of the reservoir in six patients. The mean faecal output per 24 hours was $659 \pm 259 \mathrm{~g}$ and the mean reservoir volume was $330 \pm 78 \mathrm{ml}$. Mean resting anal canal pressure was significantly lower in patients with a mucous leakage per anum than in those without, while manometry of the reservoir showed no alteration of pressure over a period of one hour before and after a meal. A positive rectosphincteric reflex was observed in nine patients.

Patients with diffuse colonic diseases such as ulcerative colitis and familial adenomatosis coli are successfully treated by proctocolectomy but at the cost of a permanent ileostomy. For this reason, operations restoring intestinal continuity have been described of which colectomy and ileorectal anastomosis is the most widely used. ${ }^{1-3}$ The great objection to this procedure is that it does not remove all the diseased tissue, as the rectum is preserved. Proctocolectomy maintaining the normal route of defaecation by ileo-anal anastomosis $^{4} 5$ avoids this disadvantage but function in these patients, in particular frequency of defaecation, is often unsatisfactory. This may in large part be due to the loss of the reservoir capacity normally afforded by the large bowel, particularly the rectum, and to the peristaltic drive of the small intestine.

The recently described operation of proctocolectomy with ileo-anal reservoir $^{6}{ }^{7}$ may well overcome this difficulty, as the average daily

*Address for correspondence: R J Nicholls, St. Mark's Hospital City Road, London.

Received for publication 16 December 1980. frequency of defaecation in a series of 21 patients was 3.8 (range 1-6) and only one had a significant disturbance of continence. ${ }^{8}$ If these initial results are maintained then eradication of disease, avoidance of an ileostomy, and preservation of satisfactory function may perhaps all be achieved.

It is, however, important to know whether any long-term metabolic or physiological disturbances can result from the operation. This has prompted a study of those patients who have been followed for more than six months postoperatively with particular reference to their haematological and biochemical state, to the bacterial content of the stool, the motility of the ileal reservoir and the anal canal, and the histological appearances of the reservoir mucosa.

\section{Methods}

The terms used to describe the anatomy after restorative protocolectomy with ileal reservoir are shown in Fig. 1. The patients were provided with a temporary ileostomy which was closed at a suitable time after this procedure. The followup period was taken to start from this date. 


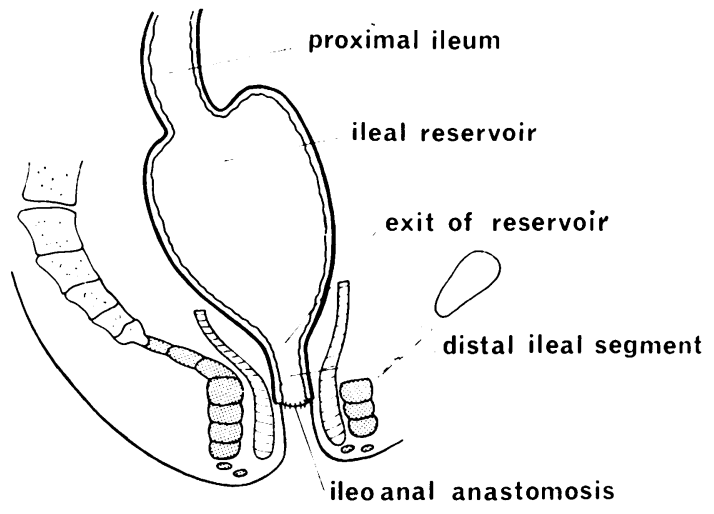

Fig. 1 The pelvic ileal reservoir and ileo-anal anastomosis.

Fourteen patients were studied; 10 had previously had ulcerative colitis and four familial adenomatosis coli. There were seven males and seven females with a mean age of 31.3 years (range 20-47 years). The temporary loop ileostomy had been closed 6-28 months (mean $17 \cdot 2$ months) previously.

Blood was taken for full blood count and estimations of plasma electrolyte concentrations and serum calcium, phosphorus, albumin, SGOT, alkaline phosphatase, iron, vitamin $\mathbf{B}_{12}$ and folate levels. Red cell folate estimations were also made. A Schilling test without intrinsic factor was carried out on 12 patients.

The patient was fasted for 12 hours and $1.0 \mathrm{mg}$ cyanocobalamin labelled with $1.0 \mu \mathrm{c} 57 \mathrm{Co}$ was given orally followed by an intramuscular injection of $1.0 \mathrm{mg}$ non-radioactive cyanocobalamin. The urine was collected for the next 24 hours and the radioactivity in it was measured. This was expressed as a fraction of the original amount of radioactivity ingested: a normal value being equal to or greater than $10 \%$ excretion in the urine and definite vitamin B.? malabsorption to less than $5 \%$. A quantitative faecal fat excretion test was done on 13 patients all taking a regular hosnital diet using a standard wet digestion method which included hydrolysis and neutralisation of the fatty acids; these were then extracted and estimated by titration. ${ }^{9} \mathrm{~A}$ fat excretion of less than $19 \mathrm{mmol}$ in 24 hours was taken as normal.

Anal manometry using a closed system was performed in all patients. Maximum anal canal pressures at rest and during voluntary contraction were recorded.

In seven patients a balloon ( $5 \mathrm{~mm}$ diameter) was placed inside the reservoir through a sigmoidoscope and a recording of intraluminal pressure was made over a 60 minute period. The patient was then given a meal and pressure recordings were continued for another 45 minutes.

The volume of the reservoir was assessed in all patients using a balloon $(30 \times 60 \mathrm{~mm})$ introduced into the reservoir per anum and gradually inflated with air until perineal and/or abdominal discomfort was experienced. The balloon was then repositioned in the distal ileal segment and resting anal canal pressure was measured as the balloon was progressively inflated by $10 \mathrm{ml}$ increments of air.

The levels of the junction of reservoir and distal ileal segment and of the ileo-anal anastomosis were determined by sigmoidoscopy and a mucosal biopsy for histological examination was taken from the reservoir in 13 patients. Samples of faeces were obtained directly from the reservoir in 12 patients during a second sigmoidoscopy. These were placed immediately into pre-weighed screw-cap bottles containing a suitable transport medium.

The specimens were homogenised and the homogenates serially diluted in an anaerobic chamber and plated on to blood agar containing $5 \%$ horse blood and MaConkey agar and removed for aerobic incubation in $5 \% \mathrm{CO}$, at $37^{\circ} \mathrm{C}$ for two davs. Three media for anaerobic culture were used. All consisted of Brucella agar base (oxoid) with $1 \mu \mathrm{g} / \mathrm{ml}$ vitamin $\mathrm{K}$ and $5 \mu \mathrm{g} / \mathrm{ml}$ haemin. The first medium contained $10 \%$ horse blood, the second $10 \%$ lysed horse blood with $7.5 \mu \mathrm{g}$ vancomycin, and $7.5 \mu \mathrm{g}$ kanamycin $/ \mathrm{ml}$, and the third $10 \%$ horse blood with $100 \mu \mathrm{g} / \mathrm{ml}$ neomycin. Anaerobic incubation was for seven davs in an atmosphere of $5 \% \mathrm{CO}_{n}, 10 \% \mathrm{H}_{n}$, and $85 \% \mathrm{H}_{\text {? }}$. at $37^{\circ}$.

Statistical comvarisons were made using the Wilcoxon rank sum test.

\section{Results}

The results of the blood investigations are shown in Table 1. One patient (case 3) had microcytic anaemia associated with low serum iron and transferrin saturation. Serum iron levels were low in four other patients (cases 4, 8, 9, and 11) without anaemia. Serum vitamin $\mathbf{B}_{12}$ levels were normal in all patients except one (case 1). Serum folate levels were low in two patients (cases 4 and 11), but all had normal red cell folate values. Plasma electrolytes, serum calcium, phosphorus, 
Table 1 Results of blood investigations

\begin{tabular}{|c|c|c|c|c|c|c|c|c|c|c|c|}
\hline \multirow[t]{2}{*}{ Case } & \multirow{2}{*}{\multicolumn{2}{|c|}{$\begin{array}{l}\text { Age, sex } \\
(y r)\end{array}$}} & \multirow{2}{*}{$\begin{array}{l}\text { Follow-up } \\
\text { (months) }\end{array}$} & \multirow{2}{*}{$\begin{array}{l}\text { Haemoglobin } \\
(\mathrm{g} / \mathrm{dl})\end{array}$} & \multirow{2}{*}{$\begin{array}{l}\text { Iron } \\
(>12 \\
\text { umol/l) }\end{array}$} & \multirow{2}{*}{$\begin{array}{l}\text { TIBC } \\
52-73 \\
\text { (umol/l) }\end{array}$} & \multirow{2}{*}{$\begin{array}{l}\text { Transferrin } \\
\text { saturation } \\
(20-50 \%)\end{array}$} & \multirow{2}{*}{$\begin{array}{l}\text { Albumin } \\
(>35 \mathrm{gil})\end{array}$} & \multirow{2}{*}{$\begin{array}{l}B_{12} \\
(160-900 \\
n g / l)\end{array}$} & \multicolumn{2}{|c|}{ Folate } \\
\hline & & & & & & & & & & $\begin{array}{l}\text { Serum } \\
(>4 \mathrm{ug} \mid l)\end{array}$ & $\begin{array}{l}\text { Red cell } \\
(>160 \\
(u g / l)\end{array}$ \\
\hline $1^{*}$ & 38 & $\mathbf{M}$ & 21 & $13 \cdot 8$ & $19 \cdot 5$ & 68 & 27 & 39 & $90 \ddagger$ & $12 \cdot 6$ & 636 \\
\hline $2^{*}$ & 24 & $\mathbf{M}$ & 24 & $14 \cdot 8$ & 18 & 85 & 22 & 44 & 420 & $4 \cdot 5$ & 223 \\
\hline $3 *$ & 26 & $\mathbf{F}$ & 27 & $10 \cdot 6 \ddagger$ & $6 t$ & 72 & $8 \ddagger$ & 38 & 850 & $3.9 \ddagger$ & 354 \\
\hline $4 \dagger$ & 34 & F & 28 & $13 \cdot 3$ & $8+$ & 852 & $15 \ddagger$ & 45 & 671 & $18 \cdot 0$ & 640 \\
\hline $6^{*}$ & 31 & $\mathbf{M}$ & 24 & $14 \cdot 9$ & 17 & 71 & 24 & 43 & 440 & 7.9 & 317 \\
\hline $7^{*}$ & 49 & $\mathbf{F}$ & 24 & 16.0 & $22 \cdot 5$ & & & 41 & 280 & $4 \cdot 8$ & 224 \\
\hline $8^{*}$ & 35 & $\mathbf{F}$ & 12 & $12 \cdot 3$ & $8 \mp$ & 63 & $13 \ddagger$ & 38 & 560 & $5 \cdot 1$ & 267 \\
\hline $9 *$ & 29 & $\mathbf{M}$ & 15 & 14.0 & $6+$ & 66 & $9 \ddagger$ & 44 & 350 & 18.0 & 640 \\
\hline $10^{*}$ & 20 & $\mathbf{F}$ & 12 & $13 \cdot 3$ & 16 & 58 & 27 & 45 & 720 & $11 \cdot 8$ & 640 \\
\hline $11^{*}$ & 31 & $\mathbf{F}$ & 9 & $14 \cdot 0$ & $11 \ddagger$ & 53 & 20 & 42 & 370 & $3 \cdot 1 \ddagger$ & 280 \\
\hline $12 \dagger$ & 25 & $\mathbf{M}$ & 6 & $13 \cdot 7$ & 19 & 82 & 23 & 43 & 480 & $9 \cdot 7$ & 367 \\
\hline $13 \dagger$ & 42 & $\mathbf{M}$ & 6 & 15.0 & 15 & 78 & $19 \ddagger$ & & 210 & $12 \cdot 5$ & 237 \\
\hline $14+$ & 16 & $\mathbf{M}$ & 7 & $13 \cdot 1 \S$ & 16 & 71 & $22^{+}$ & 49 & 520 & $6 \cdot 6$ & 245 \\
\hline
\end{tabular}

*Ulcerative colitis.

†Familial adenomatosis coli.

$\ddagger$ Abnormal value.

§-thalassaemia trait.
SGOT, and albumin levels were normal in all; alkaline phosphatase was slightly raised in three.

Schilling tests (Table 2) were normal in eight patents and slightly reduced in four (cases 3, 6, 10 , and 11). None was less than $5 \%$.

The 24 hour stool output ranged from 330 to $1180 \mathrm{~g}$ (mean $659 \pm 259 \mathrm{~g}$ ) and the faecal fat excretion was normal in all the patients.

Faecal bacterial counts $\left(\log _{10} \mathrm{cfu} / \mathrm{g}\right)$ ranged from 3.15 to 10.70 (mean $6.93 \pm 2 \cdot 1$ ) for anaerobes and from 1.30 to 8.55 (mean $5.56 \pm 2 \cdot 2$ ) for aerobes. Relative overgrowth of anaerobes $\left(>8.0 \log _{10} \mathrm{cfu} / \mathrm{g}\right.$ ) was found in three patients (cases 4,7 , and 11). Of the aerobic organisms $E$ coli predominated in seven patients and Strep faecalis in four.

Histological examination of biopsies of the mucosal lining of the reservoir showed a normal ileal villous structure in seven patients (Fig. 2a). In three there was some shortening of the villi and a total absence of villous pattern with a flattened mucosa was found in three others. In these six patients with alterations of the villi, the goblet cell population was increased and a diffuse

Table 2 Reservoir mucosal inflammation related to faecal bacterial counts and output and vitamin $B_{12}$ absorption

\begin{tabular}{|c|c|c|c|c|c|}
\hline Case & $\begin{array}{l}\text { Aerobes } \\
\left(\log _{10} c f u / g\right) \\
(3-8)\end{array}$ & $\begin{array}{l}\text { Anaerobes } \\
\left(\log _{10} c f u ! g\right) \\
(3-7)\end{array}$ & $\begin{array}{l}\text { Faecal } \\
\text { fat } \\
(>19 \mathrm{~mm}) \mathrm{l} / 24 \mathrm{~h})\end{array}$ & $\begin{array}{l}\text { Faecal output } \\
(\mathrm{g} / 24 h)\end{array}$ & $\begin{array}{l}\text { Schilling } \\
\text { test } \\
(>10 \% \text { retention })\end{array}$ \\
\hline \multicolumn{6}{|c|}{ Inflammation } \\
\hline 2 & $7 \cdot 23$ & $7 \cdot 50$ & $7 \cdot 8$ & 715 & $18 \cdot 4$ \\
\hline 3 & 4.90 & $6 \cdot 24$ & 9.6 & 540 & 8.4 \\
\hline 5 & $7 \cdot 698$ & $7 \cdot 676$ & 5.9 & 385 & $10 \cdot 6$ \\
\hline 7 & $8 \cdot 554$ & $8 \cdot 440$ & $11 \cdot 5$ & 695 & $10 \cdot 2$ \\
\hline 8 & $6 \cdot 301$ & 6.845 & $7 \cdot 1$ & 930 & $14 \cdot 0$ \\
\hline 10 & 6.995 & $6 \cdot 230$ & $19 \cdot 0$ & 975 & $7 \cdot 2$ \\
\hline Mean & $6.946^{*}$ & $7 \cdot 155$ & $10 \cdot 1$ & 707 & $11 \cdot 5$ \\
\hline$\pm \mathbf{S D}$ & $1 \cdot 251$ & 0.875 & $4 \cdot 8$ & 225 & $4 \cdot 1$ \\
\hline \multicolumn{6}{|c|}{ No inflammation } \\
\hline 1 & $1 \cdot 30$ & $3 \cdot 15$ & $2 \cdot 3$ & 520 & $21 \cdot 2$ \\
\hline 4 & 5.02 & $10 \cdot 70$ & $2 \cdot 1$ & 330 & $22 \cdot 0$ \\
\hline 6 & $3 \cdot 176$ & 3.301 & $4 \cdot 6$ & 750 & 8.6 \\
\hline 11 & 2.579 & 8.447 & 6.0 & 565 & $9 \cdot 0$ \\
\hline 12 & $7 \cdot 368$ & $7 \cdot 732$ & 3.6 & 675 & 14.7 \\
\hline 14 & $5 \cdot 176$ & $7 \cdot 699$ & $7 \cdot 1$ & 310 & $14 \cdot 5$ \\
\hline 9 & & & $10 \cdot 7$ & 1180 & \\
\hline Mean & $4 \cdot 103^{*}$ & $6 \cdot 838$ & $5 \cdot 2$ & 618 & $15 \cdot 0$ \\
\hline \pm SD & 1.779 & 3.005 & $3 \cdot 0$ & 296 & $5 \cdot 7$ \\
\hline
\end{tabular}

*Significant difference between mean counts of aerobic bacteria in inflamed and non-inflamed reservoirs $(P<0.05)$. 


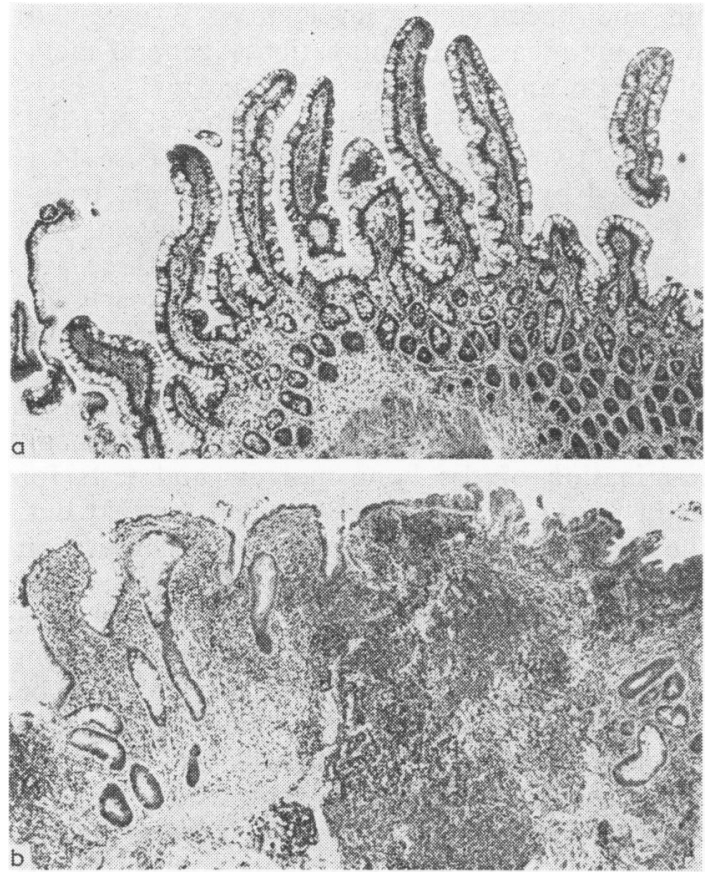

Fig. 2 (a) Mucosal biopsy from the reservoir (case 11)-normal villous pattern. $\times 60$. (b) Mucosal biopsy from the reservoir (case 5)-atrophic villi and inflammation. $\times 60$.

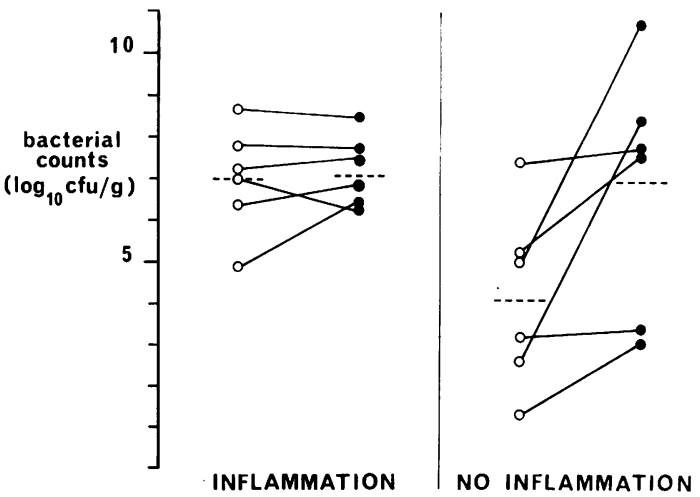

Fig. 3 The relationship between faecal bacterial counts and mucosal inflammation in the reservoir. Aerobes. Anaerobes. Significantly greater counts of aerobes with inflammation $(\mathrm{P}<0.05)$.

chronic inflammatory cell infiltrate consisting mainly of plasma cells and lymphocytes in the lamina propria and muscularis mucosae was found. In two of these (cases 5 and 10) acute inflammation with superficial ulceration and crypt abscesses was seen (Fig. 2b). The morphological appearance in those with an atrophic or absent villous pattern resembled colonic mucosa.

Inflammation was significantly associated with high faecal counts of aerobic organisms (P 0.05) but not with anaerobes, the Schilling test values,

Table 3 Results of manometric investigations

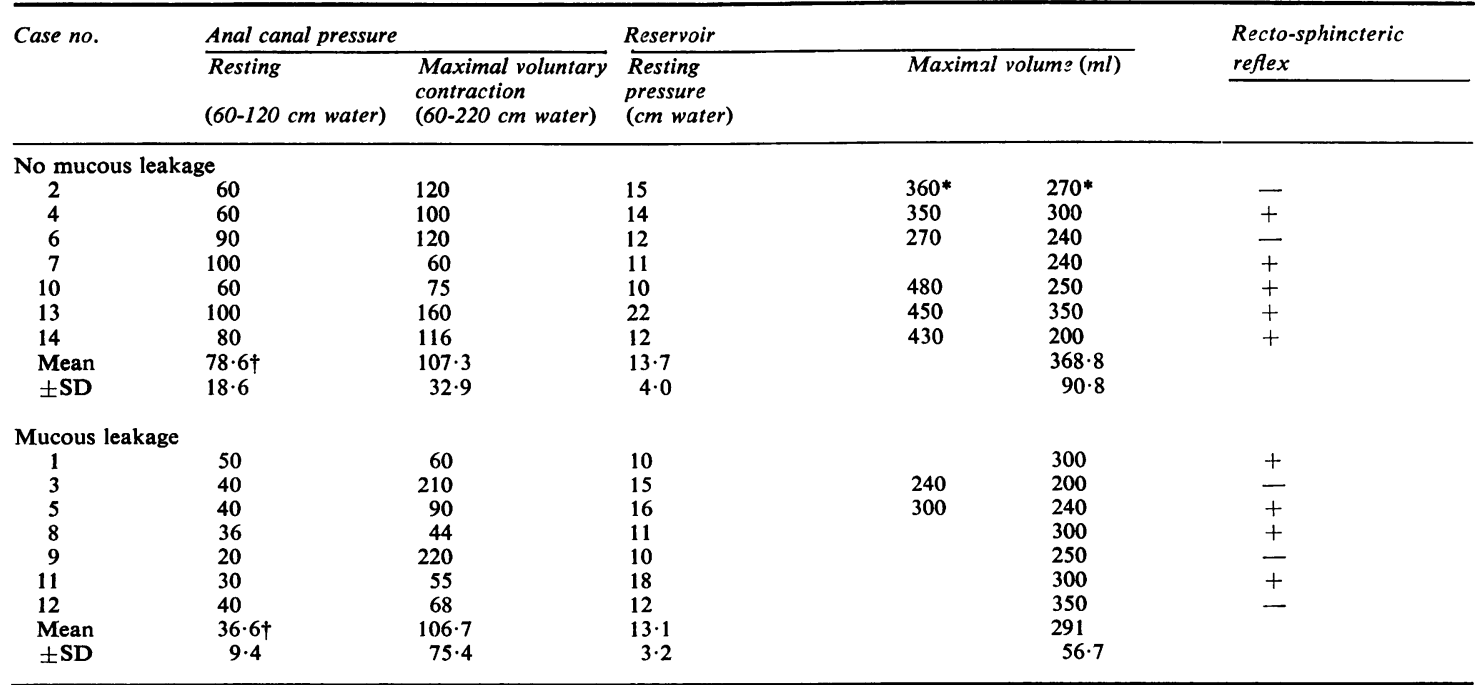

*First column: maximal volume limited by abdominal sensation.

Second column: volume ar which perineal sensation felt; when only one value given, perineal sensation limited further expansion.

†Sign ificant difference between mean anal canal resting pressure of patients with mucous leakage and those without $(\mathrm{p}<0.05)$. 
nor the faecal output per 24 hours (Table 2, Fig. 3).

As previously reported ${ }^{8}$ some patients experienced a degree (usually minor) of mucous leakage per anum and Table 3 shows the results of the manometric studies. In those with mucous leakage resting anal canal pressures were lower $\left(37 \pm 9 \mathrm{~cm} \mathrm{H}_{2} \mathrm{O}\right)$ compared with those without $\left(79 \pm 19 \mathrm{~cm} \mathrm{H}_{2} \mathrm{O}\right.$ ). This difference was statistically significant $(\mathrm{P}<0.05)$. Maximal voluntary contraction pressures were, however, no different in those who had mucous leakage $(106.7 \pm 75.4 \mathrm{~cm}$ $\left.\mathrm{H}_{2} \mathrm{O}\right)$ and those who had not $(107.3 \pm 32.9 \mathrm{~cm}$ $\mathrm{H}_{2} \mathrm{O}$ ).

Intrareservoir resting pressures were steady during the period of recording and ranged from $10-22 \mathrm{~cm} \mathrm{H}_{2} \mathrm{O}$ (mean $13 \cdot 4 \pm 3 \cdot 5$ ); there was no change after eating a meal. The maximal volume of intrareservoir distension that could be tolerated ranged from 240 to $480 \mathrm{ml}$ (mean $330 \pm$ $78 \mathrm{ml}$ ). Distension was limited by abdominal discomfort in eight patients but most patients experienced a sensation of perineal fullness at lower volumes similar to the feeling of the desire to evacuate that they used to have before the proctocolectomy.

Distension of the distal ileal segment caused a fall in resting anal canal pressure in nine out of 14 patients. The maximal threshold volume of this response ranged from 30 to $100 \mathrm{ml}$. The ileo-anal anastomosis lay between 3 to $5 \mathrm{~cm}$ from the anal verge (mean $3.6 \pm 0.7 \mathrm{~cm}$ ) and the exit of the reservoir varied from 7 to $12 \mathrm{~cm}$ (mean $9 \cdot 1 \pm 1.4 \mathrm{~cm}$ ) from the anal verge.

\section{Discussion}

The immediate outcome of restorative proctocolectomy with ileal reservoir has so far been encouraging. As reported recently ${ }^{8}$ the procedure effectively restores the patient with ulcerative colitis to normal health with no more hazard than any other major pelvic operation and acceptable functional results in almost every case. Many operations-for example, gastrectomycan, however, lead to physiological disturbances in the longer term and it is clear that the patients reported here should be continuously followed up.

The investigation was intended as a general screening procedure to see whether any gross metabolic disturbances had developed and a detailed analysis of some of the abnormalities that were uncovered-for example, the low serum iron values found in some patients-was not undertaken therefore. The normal plasma albu- min and haemoglobin levels (case 3 excepted) give some measure of the patients' general metabolic state and the consistently normal electrolyte and calcium concentrations are reassuring. The slightly low haemoglobin level in case 14 is explained by the co-existing thalassaemia trait.

The low serum iron levels in five patients and the low serum folate levels in two of these are, however, a cause for concern. Case 3 clearly has an iron deficiency anaemia, but in the other four the significance of the low iron values is not clear, as TIBC levels were normal, although transferrin saturation was low in three of them; examination of the bone marrow and tests for occult blood in the stool were not carried out. The abnormality was not related to inflammation in the pouch nor to the original diagnosis of ulcerative colitis or polyposis. Four of the patients were premenopausal women in whom iron deficiency is common but it could also be possible that there has been abnormal iron loss postoperatively in these patients or that iron losses resulting from the original disease ${ }^{10}$ or the operation itself had not been replenished by the time of the study. Red cell folate concentrations were normal in all the patients and there is, therefore, no evident folate deficiency anaemia despite low serum values in cases 3 and 11 . It is not known why case 1 had a low vitamin $\mathbf{B}_{12}$ level, although it might be dietary in cause as the patient is a strict vegetarian.

As with the reservoir ileostomy developed by Kock, ${ }^{11}$ the operation leaves the patient with a pouch of small bowel in which faeces may remain for considerable periods of time. Both operations could, therefore, potentially lead to a stagnant loop syndrome as a result of bacterial overgrowth in the reservoir due to stasis. ${ }^{12}$ This would be suggested by evidence of fat and vitamin $\mathbf{B}_{12}$ malabsorption combined with weight loss and high faecal bacterial counts. ${ }^{12} 13$

So far, none of the patients studied has fulfilled these criteria. Faecal fat excretion was normal in all and there was no overt case of vitamin $\mathbf{B}_{12}$ malabsorption, although Schilling tests were slightly reduced in four. The counts of bacteria within the reservoir exceeded the upper limit for faeces in the normal terminal ileum of $8(\log \mathrm{cfu} / \mathrm{gm})^{14}$ in only one patient, although the absence of bacterial overgrowth in the remainder cannot be assumed, as the length of ileum colonised was not measured. These observations are broadly similar to some studies of patients with Kock ileostomies ${ }^{15} 16$ but, as Schornsby et al..$^{17}$ have shown, a stagnant loop syndrome can follow this operation. Five out of 
seven patients investigated at six to 52 months after Kock reservoir operations had raised faecal fat outputs and low Schilling tests. The latter could be restored to normal by oral lincomycin, which also reduced the concentration of bacteroides in the faeces.

It is clear, therefore, that repeated assessment of the patients reported here is necessary in the future, although it is reasonable to conclude that, so far, a stagnant loop syndrome has not occurred.

Histopathological examination of biopsies taken from the ileal reservoir showed abnormalities in nearly half the patients and similar changes may occur in Kock reservoir ileostomies. ${ }^{18}$ The association of inflammation with higher counts of aerobic organisms in the faeces suggests the possibility of a causal relationship. Additional studies with more patients should, however, be carried out along with more detailed examination of faecal organisms-for example, to determine whether invasive strains or toxin producers are found in the presence of inflammation. It is noteworthy that patients with reservoirs showing inflammation all had colitis originally. If it transpires that the cause of the inflammation is bacterial, then it should at least be possible to improve it with anti-bacterial drugs. So far, however, the presence of inflammation in the pouch has not caused any obvious clinical disturbance and, as already mentioned, there is no evidence at present of stagnant loop syndrome in these patients.

The volumes of faeces passed per day were similar to the expected output from a terminal ileostomy ${ }^{19}$ and no greater in those patients with inflammation in the reservoir. The unchanging intraluminal pressure even after a meal indicates that at low volumes, at least for a period of one to two hours, there is little tendency to evacuation as a result of intrinsic motility of the reservoir. Even with a greater degree of distension contraction of the pouch did not seem to take place, as no patient experienced colicky pain on inflation of an intraluminal balloon to maximally tolerated volumes. Phasic contractions of Kock reservoirs have, however, been observed at volumes above $600 \mathrm{ml} .{ }^{20}$ The volumes of the reservoir in the patients reported here were about 100 to $200 \mathrm{ml}$ less than those measured in Kock ileal reservoirs; ${ }^{21}$ this suggests that it is either smaller or that its expansion is restricted by the pelvis or by the rectal muscle tube which invests its lower part. It might also be that the reservoir is less likely than the Kock reservoir to distend with the passage of time, as the need to empty it will be felt at lower volumes because of preserved rectal sensation.

Mucous leakage appears to be due to reduced internal anal sphincter activity, as resting anal canal pressure is largely maintained by this muscle and the normal voluntary contraction pressures in all patients but one (case 8 ) indicate that external sphincter function was well maintained. Whether internal sphincter impairment resulted from the operation is not known, as preoperative manometry was not carried out. It is possible that its tone was reduced by the anal stretching necessary to perform the ileo-anal anastomosis, but it may be that the distal ileal segment terminating as it does in most cases within $4 \mathrm{~cm}$ of the anal verge can prevent complete closure of the anal canal. Mucous leakage was not related to whether or not the patient used a catheter for evacuation.

Reflex inhibition of the internal sphincter on distending the distal ileal segment was found to occur in over half the patients. Lane and Parks ${ }^{22}$ made a similar observation in patients with coloanal anastomosis and they speculated that nervous plexuses within the gut distal and proximal to the anastomosis had established functional connections. It seems more likely, however, that in this particular operation the reflex had never been interrupted, as the lower rectal and pelvic floor musculature is preserved by the procedure.

In conclusion, no serious metabolic disturbance has so far occurred in this group of patients treated by restorative proctocolectomy and ileal reservoir more than six months before assessment. Some abnormalities were found, however, and perhaps the most significant of these was the association of higher faecal aerobic bacterial counts with the presence of mucosal inflammation of the reservoir. At present, however, this does not appear to have affected adversely intestinal absorption or the physiological behaviour of the reservoir or the anal canal; regular assessment of these patients is necessary however.

The authors wish to thank Sir Alan Parks for his permission to study his cases and the Research Foundation of St. Mark's Hospital and the RS MacLaughlin Foundation, Canada, for their financial support. We are grateful to $\mathrm{Dr}$ BC Morson (Department of Histopathology, St Mark's Hospital), and Professor D Mollin (Department of Experimental Haematology, St Bartholomew's Hospital) for their help. Dr J Powell-Tuck kindly commented on the manu- 
script and $\mathrm{Mr} \mathrm{N}$ Mackie and Mrs J Mackie (Department of Medical Illustration, St Mark's Hospital) provided the illustrations; we also thank Mrs D Brockhurst for her secretarial assistance.

\section{References}

'Aylett SO. Three hundred cases of diffuse ulcerative colitis treated by total colectomy and ileorectal anastomosis. Br Med J 1966; 1:1001-5.

${ }^{2}$ Jones PF, Munro A, Ewen SWB. Colectomy and ileo-rectal anastomosis for colitis: report on a personal series, with a critical review. Br J Surg 1977; 64:615-23.

${ }^{B}$ Bussey HJR. Familial polyposis coli. In: Pathology Annual 1979; 14:61-81.

'Ravitch MM. Anal ileostomy with sphincter preservation in patients requiring total colectomy for benign conditions. Surgery 1948; 24:170-87.

${ }^{5}$ Martin L, Le Coultre C, Schubert WK. Total colectomy and mucosal proctocolectomy with preservation of continence in ulcerative colitis. $A n n$ Surg 1977; 186:47-80.

${ }^{6}$ Parks AG, Nicholls RJ. Protocolectomy without ileostomy for ulcerative colitis. $\mathrm{Br} M e d \mathrm{~J}$ 1978; 2: 85-8.

${ }^{7}$ Fonkalsrud EW. Total colectomy and endorectal pull-through with internal ileal reservoir for ulcerative colitis. Surg Gynecol Obstet 1980; 150:1-8.

${ }^{8}$ Parks AG, Nicholls RJ, Belliveau P. Protocolectomy with ileal reservoir and anal anastomosis. $\mathrm{Br}$ J Surg 1980; 67:533-8.

${ }^{9}$ Kamer Van de JH, ten Bokkel Huinik H, Weyers HA. Rapid method for determination of fat in faeces. J Biol Chem 1949; 177:347-55.

${ }^{10}$ Beal RW, Skyring AP, McRae J, Firkin BG. The anaemia of ulcerative colitis. Gastroenterology
1963; 45:589-603.

${ }^{11}$ Kock NG. Intra-abdominal 'reservoir' in patients with permanent ileostomy. Arch Surg 1969; 99: 223-31.

${ }^{12}$ Tabaqchali $S$. The pathophysiological role of small intestinal bacterial flora. Scand J Gastroenterol 1970; suppl 6:139-63.

${ }^{13}$ Donaldson RM. Blind loop syndrome. In: Sleisenger $\mathrm{MH}$, Fordtran JS, eds. Gastrointerstinal disease. Philadelphia: Saunders, 1978: 1094-103.

${ }^{14}$ Gorbach SL, Plaut AG, Nahas L, Weinstein L, Spanknebel G, Levitan MD. Studies of intestinal microflora. Gastroenterology 1967; 53:856-67.

${ }^{15}$ Nilsson LO, Andersson H, Hulten L, et al. Absorption studies in patients six to 10 years after construction of ileostomy reservoirs. Gut 1979; 20:499-503.

${ }^{16}$ Jagenberg R, Kock NG, Philipson B. Vitamin $B_{12}{ }^{-}$ absorption in patients with continent ileostomy. Scand J Gastroenterol 1975; 10:141-4.

${ }^{17}$ Schjonsby H, Halvorsen JF, Hofsad T, Havdenak N. Stagnant loop syndrome in patients with contients with continent ileostomy (intra-abdominal ileal reservoir). Gut 1977; 18:795-9.

${ }_{18}$ Philipson B, Brandberg A, Jagenberg R, Kock NG, Lager I, Ahren C. Mucosal morphology, bacteriology and absorption in intra-abdominal ileostomy reservoir. Scand J Gastroenterol 1975; 10:145-53.

${ }^{19} \mathrm{Hill}$ GL. Ileostomy, surgery, physiology and management. New York: Grune and Stratton, 1976.

${ }^{20}$ Gadacz TR, Kelly KA, Phillips SF. The continent ileal pouch: absorptive and motor features. Gastroenterology 1977; 72:1287-91.

${ }^{21}$ Kock NG, Darle N, Hulten L, Keweuter J, Myrvold H, Philipson B. Ileostomy. Current problems in surgery 1977; 14(8):1-52.

${ }^{22}$ Lane RHS, Parks AG. Function of the anal sphincters following colo-anal anastomosis. $\mathrm{Br} \mathrm{J}$ Surg $1977 ; 64: 596-9$. 